\title{
Simultaneous-HPLC Quantification of Phenolic Acids in Traditionally used Ayurvedic Herb Diplocyclos palmatus (L.) Jeffry
}

\author{
Ankita Misra, Pushpendra Kumar Shukla, Bhanu Kumar, Abhishek Niranjan, AKS Rawat and Sharad Srivastava*
}

\section{Ankita Misra, Pushpendra Kumar Shukla, Bhanu Kumar, Abhishek Niranjan, AKS Rawat and Sharad Srivastava*}

\section{Pharmacognosy and}

Ethnopharmacology Division, CSIR-National Botanical Research Institute Lucknow (U.P.) 226001, INDIA.

\section{Correspondence}

Dr. Sharad Srivastava, Pharmacognosy and Ethnopharmacology Division, CSIRNational Botanical Research Institute Lucknow (UP) 226001, (Is), INDIA.

Phone: 91-522-2297816;

Fax: 91-522-2205836

E-mail: sharad_ks2003@yahoo.com

\section{History}

- Submission Date: 23-01-2017;

- Review completed: 07-03-2017;

- Accepted Date: 13-03-2017

DOI : 10.5530/pj.2017.4.78

Article Available online

http://www.phcogj.com/v9/i4

\section{Copyright}

(C) 2017 Phcog.Net. This is an openaccess article distributed under the terms of the Creative Commons Attribution 4.0 International license.

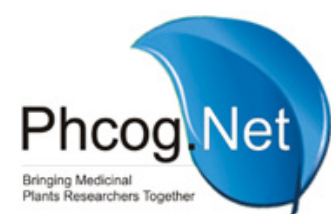

\begin{abstract}
Introduction. The present study deals with the simultaneous HPLC-quantification of phenolic acid(s) in the aerial parts of Diplocyclos palmatus (Cucurbitaceae) and evaluation of their bioactivity potential through in vitro antioxidant assay's. Method. The HPLC elution was done using $\mathrm{C}_{18}$ column using gradient (binary phases) solvent system at a flow rate of $0.6 \mathrm{ml} / \mathrm{min}$. Total phenolic and, flavonoid contents were determined and the antioxidant potential was estimated by four assay's viz. DPPH radical scavenging assay, ferric reducing power assay, total antioxidant capacity and 2-deoxy ribose assay. Results. The species is rich in three phenolic acids, among which gallic acid $(1708 \mathrm{ug} / \mathrm{g})$ is in maximum concentration followed by caeffic acid $(437 \mathrm{ug} / \mathrm{g})$ and protocateuchic acid $(337.7 \mathrm{ug} / \mathrm{g})$. Total phenolic content was higher $(10.5 \mathrm{mg} / \mathrm{g})$ than flavonoid content $(3.78 \mathrm{mg} / \mathrm{g})$ and TAC was found at $0.137 \mathrm{mg} / \mathrm{g}$ ASE (ascorbic acid equivalent). $I C_{50}$ of $D$. palmatus extract for scavenging of hydroxyl radical by 2-deoxy ribose and DPPH was at concentration of $125.61 \pm 0.834(\mu \mathrm{g} / \mathrm{ml})$ and $353.71 \pm 0.663(\mu \mathrm{g} / \mathrm{ml})$ respectively. In vitro antidiabetiv potential, via inhibition of alpha amylase enzyme through starch iodine and 3,5- DNS assay reveals the $\mathrm{IC}_{50}$ of extract at $146.31 \pm 0.415 \mathrm{ug} / \mathrm{ml}$ and $286.23 \pm 0.671 \mathrm{ug} / \mathrm{ml}$ respectively. Conclusion. The species (aerial part) was rich in phenolic acid with potential bioactivity, identified leads will be usefull in further chemical characterization and pharmacological validation.

Key words: Diplocyclos palmatus, HPLC, Phenolic acid, Anti oxidant, Anti diabetic.
\end{abstract}

\section{INTRODUCTION}

Diplocyclos palmatus (L.) C. Jaffery (Cucurbitaceae), commonly known as "shivlingi" is ethnobotanically a highly valuable plant and is distributed widely in India as a climbing weed. ${ }^{1}$ In traditional systems of medicine, almost every part of the plant has medicinal property and is widely used by traditional healers for inflammation, jaundice and fever conditions., ${ }^{2,3}$ The Bhilla tribe of Maharashtra (India) use seed powder in gynaecological problems, ${ }^{4}$ whereas tribes of Akole tahsil (Maharashtra) use the decoction of root to cure bronchitis, however literature regarding scientific validation of the same was not available. ${ }^{5}$ In Ayurvedic system of medicine this species is well known for treating reproductive disorders, ${ }^{6}$ in male and female infertility and also, to prevent miscarriage. ${ }^{7}$

The plant is known to have alkaloids, saponins, phenols, steroids and cardiac glycosides etc. ${ }^{8}$ In vitro studies revealed that $D$. palmatus (aerial part) contain antioxidant and anti-microbial activity. ${ }^{9} 10$ Seeds have analgesic, anti-inflammatory and antiarthritic activity. ${ }^{11}$ In vivo anticonvulsant activity of leaves were also studied and chloroform extract was found to be more potential than aqueous and alcoholic extracts in controlling both MES and PTZ convulsions. ${ }^{12}$

D. palmatus seeds have antidiabetic potential, a dose of $150 \mathrm{mg} / \mathrm{Kg}$ results in $53.8 \%$ decrease in fasting blood glucose level. ${ }^{13}$ The leaves of the plant are used as an ingredient in special dietary preparation by tribals of Chhattisgarh region, as a tonic and as antidote in snake bite. ${ }^{14}$ However with the passage of time, importance of this Ayurvedic herb diminishes essentially due to upsurge of various other potential natural dietary sources/ medicinal herb and secondary due to extinction/ concentration of tribals and their associated knowledge.

Hence, through this study an attempt is made to scientifically explore the potential of $D$. palmatus aerial part and bring it to the scientific desk for further promotion of its usage in rurals for health benefits. To the best of our knowledge this is first ever report on identification of phenolic acid(s) in targeted species and evaluation of its biological potential.

\section{MATERIAL AND METHODS}

\section{Plant materials}

Fresh sample of D. palmatus were collected in the month of October to November from the nearby area of Varanasi (Phytogeographical zone: Gangetic plains, $81 \mathrm{~m}, 25.3176^{\circ} \mathrm{N}, 82.9739^{\circ} \mathrm{E}$ ), Uttar Pradesh, India. The sample was authenticated, and a voucher specimen was deposited in institute's herbarium (LWG No. 254028). 


\section{Standard solutions and reagents}

Reference standards viz., Gallic acid ( $\geq 95 \%)$, protocatechuic acid ( $\geq 97 \%)$, chlorogenic acid ( $\geq 97 \%)$, Caffeic acid $(\geq 97 \%)$, ferulic acid $(\geq 99 \%)$, rutin $(\geq 95 \%)$, kaempferol $(\geq 97 \%)$ and quercetin ( $\geq 97 \%)$ and 1-1-diphenyl2-picrylhydrazyl ( $\geq 99 \%$, DPPH) were purchased from Sigma-Aldrich. HPLC grade solvents viz., acetonitrile, methanol, water, and all other solvents/chemicals (AR grade) were purchased from Merck, Mumbai, India.

\section{Preparation of samples}

The plant material was manually screened for any impurities and dried in shade, followed by drying in hot air oven at $45^{\circ} \mathrm{C}$ and then powdered with an electric grinder. The coarse powder ( $40 \mathrm{mesh}$ ) was subjected to cold maceration with $100 \%$ methanol. Extracts were continuously stirred for $6 \mathrm{hrs}$ and kept up to $18 \mathrm{hrs}$ at room temperature. The process was repeated thrice, filtered (whatmann No.4) and the pooled filterate was concentrated in a rotatory evaporator (Buchi rotavpour, Switzerland) under controlled condition of temperature $\left(40 \pm 2^{\circ} \mathrm{C}\right)$ and pressure (40 bar). The extract was finally freeze dried and stored at $4^{\circ} \mathrm{C}$ for further use. $10 \mathrm{mg} / \mathrm{ml}$ of methanol extract was used for in vitro methods.

\section{HPLC Quantification of phenolics}

Preparation of stock and working solution

The standard stock solutions ( $1 \mathrm{mg} / \mathrm{mL}$ ) of phenolic acids (PA's) standard viz. gallic acid (GA), protocatechuic acid (PCA), chlorogenic acid (ChA), caffeic acid (CA), rutin (RT), ferulic acid (FA), quercetin (Qu) and kampferol (Ka) were prepared in HPLC grade methanol and stored at $4{ }^{\circ} \mathrm{C}$, until used. Working solutions of lower concentration $(0.1 \mathrm{mg} / \mathrm{mL})$ were prepared by appropriate dilution of the stock solutions in methanol.

\section{Preparation of plant extract.}

The powdered plant material ( $5 \mathrm{~g}$ ) was successively extracted thrice in methanol:water $(50 \mathrm{~mL}, 50: 50 \mathrm{v} / \mathrm{v})$ overnight on an orbital shaker at room temperature. The combined plant extract $(150 \mathrm{~mL})$ was centrifuged $(8000 \mathrm{xg})$ for $10 \mathrm{~min}$ to remove debris and concentrated up to half of the volume $75 \mathrm{~mL}$ under reduced pressure and temperature on a rotary evaporator (Büchi, USA). The extract was fractionated against ethyl acetate $(75 \mathrm{~mL})$ three times with $75 \mathrm{~mL}$ each and then concentrated on a rotary evaporator. The obtained residue was freeze-dried (Freezone 4.5, Labconco, USA) under high vacuum $(133 \times 104 \mathrm{mBar})$. A sample $(5 \mathrm{mg})$ of the extract was dissolved in HPLC grade methanol $(10 \mathrm{~mL})$, filtered with membrane syringe filter (milipore) before injecting into the HPLC.

\section{HPLC conditions}

Separation followed by qualitative and quantitative analysis of polyphenols was performed by using HPLC-UV (Shimadzu LC-10A, Japan) equipped with dual pump LC-10AT binary system, UV detector SPD-10A at $254 \mathrm{~nm}$, rheodyne injection valve furnished with a $20 \mathrm{ml}$ loop, on phenomenex Luna RP-C 18 column $(4.6 \times 250 \mathrm{~mm}$, i.d., $5 \mathrm{~mm}$ pore size) preceded with guard column of same material. Data was integrated by Shimadzu class VP series software and results were obtained by comparison with standards. Results are the mean values of three replicates of the same sample. Elution was carried out at a flow rate of $0.6 \mathrm{ml} / \mathrm{min}$ with water:acetic acid $(99.0: 1.0 \mathrm{v} / \mathrm{v})$ as solvent $\mathrm{A}$ and acetonitrile as solvent $\mathrm{B}$ using a gradient elution in $0-14$ min with $20-35 \%$ of solvent B, $14-40$ min with $35-50 \%$ of solvent B. The buffer and acetonitrile were filtered through $0.45 \mathrm{~mm}$ nylon filter and de-aerated in ultrasonic bath before use. Method was also validated for linearity, range, specificity, sensitivity, precision and system suitability.

\section{In-vitro antioxidant activity}

Total flavonoids ${ }^{15}$ and phenolics ${ }^{16}$ were expressed in terms of $\mathrm{mg} / \mathrm{g}$ of quercetin equivalent $(\mathrm{QE})$ and $\mathrm{mg} / \mathrm{g}$ gallic acid equivalent (GAE) based on calibration curve of quercetin and gallic acid as standard. The radical scavenging potential of $D$. palmatus were analysed by four different assay viz. Ferric reducing assay, ${ }^{17}$ phospho-molybdate assay, ${ }^{18} 2$-deoxyribose assay $^{19}$ and DPPH radical scavenging assay. ${ }^{20}$

\section{RESULTS}

A review of literature on the traditional knowledge about $D$. palmatus reveals that the herb is conventionally used since long ago among tribals and rural people as a potential remedy for many reproductive disorders but due to lack of considerable focus on healthcare system of such communities, this highly valuable herb is losing its charm. However, the therapeutic potential of the species viz. fruit, leaves etc. is sparingly documented. Hence we explored the antioxidant and, antidiabetic potential of its aerial part to create a preliminary background data source which can be utilised in near future to examine other biological properties. This further aids to the knowledge of locals for its encouraged use due to medicinal action.

\section{Quantification of identified phenolic acid(s) (PA's)}

The methanolic extraction of the powdered drug yielded an extractive value of $140 \mathrm{mg}$. HPLC for quantification of the phenolic acids in the extract revealed the presence of three marker compounds out of eight analyzed standard mixture solution (Figure 1). Among the identified markers gallic acid (1708 ug/g), was found in heighest concentration followed by caeffic acid (437 ug/g) and protocateuchic acid (337.7 ug/g) as shown Table 1. The identification of PA's was based on a comparison of retention times and UV spectra of reference standard(s) with the corresponding peaks in the extract. It is noteworthy that the identied markers are not common in nature and thus can be used as characterstic marker for quality control of the herb. Beside this, the bioactivity of phenolic acids is well evident as underlying cause of various disorders. ${ }^{21}$ Linearity calibration for standards were analysed at $0.5-50 \mu \mathrm{g} / \mathrm{g}$. LOD and LOQ were within the acceptable limit as per ICH guidelines. The method was found to be linear under regression analysis of area Vs. concentration of standard(s). ${ }^{22}$ To the best of our knowledge this is first ever report on HPLC quantification of phenolics in D. palmatus.

\section{Antioxidant activity}

Quantification of phenolic acid(s) lead us towards identification/detection of their bioactivity, in lieu of which polyphenolic content was spectroscopically analysed in reference to standard compound $(0.1 \mathrm{mg} / \mathrm{ml})$. Total phenolics were found to be higher than total flavonoids exhibiting straight line regression equation and statistically accepted regression coefficient (Table 2).

The reducing power of extract was estimated by reducing the ferric ion in presence of folin's phenol reagent. The reducing power of $D$. palmatus increases linearly (eq: $y=0.0013 x-0.0746, r^{2}=0.988$ ) with increase in concentration as shown in Figure 2, similar to reference standard(s) viz. ascorbic acid, quercetin, rutin and $\mathrm{BHT}^{21}$. In order to anlyse the antioxidant potential of non polar part of $D$. palamtus extract, total antioxidant capacity (TAC) was evaluated by phosphomolydneum method. IC $_{50}$ of extract was found to be $0.137 \mathrm{mg} / \mathrm{g}$ ASE (ascorbic acid equivalent) based on calibration curves of standard ascorbic acid $(0.1 \mathrm{mg} / \mathrm{ml})$. Linear curve fitting was observed by five dilutions (20-100 $\mu \mathrm{l})$ of standard exhibiting the regression coefficient of 0.996 and eq: $y=0.0081 x-0.0576$. Residual plot of standards in quantative estimation of polyphenolics and ascorbic acid in TAC also reveals the linear fitting of dilutions.

$\mathrm{IC}_{50}$ of $D$. palmatus extract in 2-deoxy ribose was found at a concentration of $125.61 \pm 0.834(\mu \mathrm{g} / \mathrm{ml})$. The scavenging effect of $\mathrm{DPPH}$ radical was concentration dependant and potentially varied for ascorbic acid, quercetin, rutin, butylated hydroxy toluene (BHT) and plant extract. 
Table 1: Qualitative (HPLC) identification of phenolic acid(s) in D. palmatus aerial part

\begin{tabular}{cccc}
\hline Sample & Phenol acid(s) & Value $(\mathrm{ug} / \mathrm{g})^{*}$ & $\mathbf{R}_{\mathrm{t}}(\mathrm{min})$. \\
\hline D. palmatus & Gallic acid & $1708.2 \pm 0.04$ & $6.38 \pm 0.030$ \\
& PCA & $337.7391 \pm 0.014$ & $8.04 \pm 0.032$ \\
& CA & $437.2536 \pm 0.035$ & $11.93 \pm 0.113$ \\
\hline
\end{tabular}

${ }^{*}$ Values are mean \pm S.D, $\mathrm{n}=3$

Table 2: Quantification of phenolic acid(s) in methanolic extract of D. palmatus

\begin{tabular}{ccccc}
\hline Sno. & Polyphenolics $^{\mathrm{a}}$ & Values $^{\mathrm{b}}$ & $\begin{array}{c}\text { Regression } \\
\text { equation }(\mathbf{y})\end{array}$ & $\begin{array}{c}\text { Regression } \\
\text { equation }\left(\mathrm{r}^{2}\right)\end{array}$ \\
\hline 1. & $\begin{array}{c}\text { Total phenolic } \\
\text { content }\end{array}$ & $10.5 \pm 0.025$ & $115.9 \mathrm{x}+0.113$ & 0.998 \\
2. & $\begin{array}{c}\text { Total flavonoid } \\
\text { content }\end{array}$ & $3.78 \pm 0.05$ & $74.61 \mathrm{x}+0.058$ & 0.997 \\
\hline
\end{tabular}

${ }^{a}$ TotalphenolicsarerepresentedasmgGallicacid/gmofdryweight, totalflavonoidsare represented as mg quercetin/gm of dry weight., ${ }^{b}$ Values are mean \pm S.D, $n=3$

Table 3: Correlations between the $\mathrm{IC}_{50}$ values of $D$. palmatus extract in DPPH radical scavenging, 2-deoxy ribose method and TPC, TFC content

\begin{tabular}{cccc}
\hline \multirow{2}{*}{ S.no } & Assay $\left(\mathrm{IC}_{50} \mathrm{ug} / \mathrm{ml}\right)$ & \multicolumn{2}{c}{ Co relation coefficient $\left(\mathrm{r}^{2}\right)^{*}$} \\
\cline { 3 - 4 } & & TPC & TFC \\
\hline 1. & 2- deoxy ribose method & 0.945 & 0.785 \\
2. & DPPH radical scavenging assay & 0.983 & 0.463 \\
\hline
\end{tabular}

${ }^{\star}$ Indicating significance at $\mathrm{p}<0.01$.

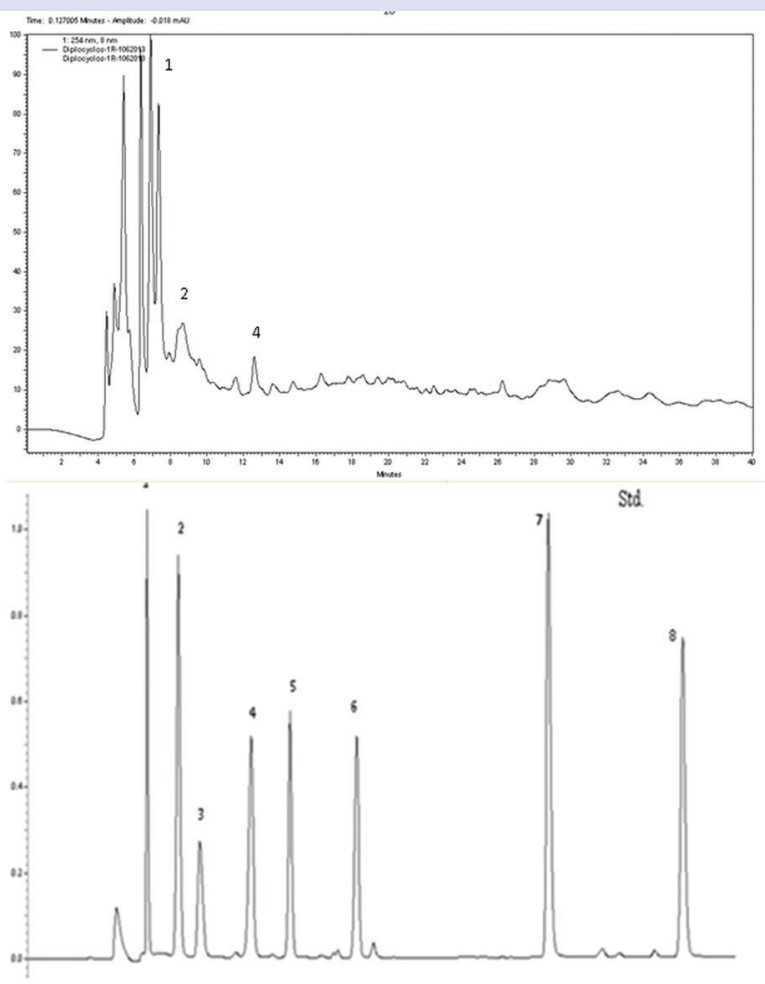

Figure 1: HPLC chromatograms of standard mixture (Std) and sample (E) at $254 \mathrm{~nm}$. (1- Gallic acid; 2- Protocatechuic acid; 3- Chlorogenic acid; 4- Caffeic acid; 5- Rutin; 6- Ferulic acid; 7- Quercetin; 8- Kampferol and extract (E) of D. palmatus.

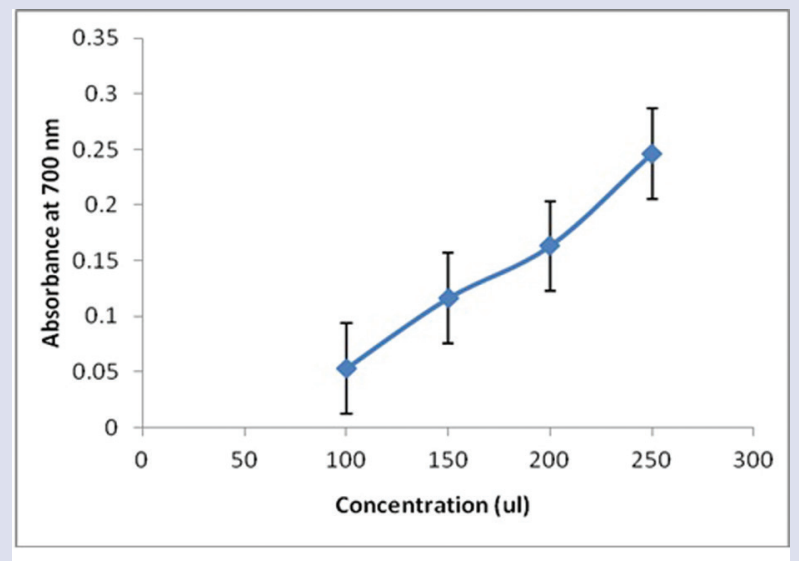

Figure 2: Linear increase in reducing power of Diplocyclos extract with increase in concentration as absorbance increases.

Ascorbic acid exhibits maximum inhibition of $77.57 \%$ which is followed by quercetin, rutin and BHT having inhibition of $72.43,71.48$, and $62.10 \%$ respectively.

Inhibition (\%) of extract varies from $31.25-66.9 \%$ at a concentration range of $0.2 \mathrm{mg} / \mathrm{ml}$ to $1 \mathrm{mg} / \mathrm{ml} \mathrm{IC}_{50}$ of extract was observed to be 353.71 $\pm 0.663(\mu \mathrm{g} / \mathrm{ml})$, significantly different from standard and decreased in order of D. palmatus extract $>$ rutin $>$ quercetin $>$ ascorbic acid $>$ BHT and hence indicating that $\mathrm{BHT}$ is potent inhibitor of free radical in all.

In adiition to this, the traditional claim of $D$. palmatus as antidiabetic was well reported in seed, however an attempt was made to evaluate the same in aerial part(s). Antidiabetic potential of D. palmatus aerial part are evaluated by in vitro models via inhibition of alpha amylase enzyme. Inhibitory activity of extract on $\alpha$-amylase was observed at a concentration range of $0.2-1 \mathrm{mg} / \mathrm{ml}$. In starch iodine and 3,5- DNS assay, $\mathrm{IC}_{50}$ of plant extract was found at $146.31 \pm 0.415 \mathrm{ug} / \mathrm{ml}$ and $286.23 \pm 0.671 \mathrm{ug} / \mathrm{ml}$ respectively. Analysis of variance among the plant extract and standard acarbose are statistically significant, ${ }^{23}$ however potential biological activity was obtained in the plant extract by both the models.

\section{CONCLUSION}

The available literature on D. plamatus reveals its traditional medicinal usage, although scientific literature scarcely available on its pharmacological properties. Fruit and seeds are the most commonly used parts and thus we made an attempt to explore the medicinal potential of its aerial part, which can be utilized for various medicinal purposes in near future. It is interesting to note that the extract contains high content of phenolic acid(s) and is characterized by presence of therapeutically valuable phenolics viz. chlorogenic acid, gallic acid, caeffic acid and protocateuchic acid. This is further confirmed by high phenolic content accompanied with high antioxidant activity. The traditional claim of species as antidiabetic drug was also revalidated through in vitro assays. Hence, the study was conducted to explore and highlight the therapeutic properties of this underutilized Ayurvedic herb. The study needs be further elaborated for more detailed chemical characterization and pharmacological inspection of $D$. palmatus.

\section{ACKNOWLEDGEMENT}

The authors are thankful to the Director, CSIR-NBRI for providing facilities and encouragement throughout the work. Thanks are also due to the technical staff for their support. 


\section{CONFLICT OF INTEREST}

None

\section{REFERENCES}

1. Kirtikar KR, Basu BD. In E. Blatter, et al. (Eds). Indian Medicinal Plants. 1987;2(2):1158-9.

2. Chopra RN. 2002. In Glossary of Indian Medicinal plants. National Institute of Science Communication and Information Resources (CSIR), New Delhi; 165.

3. Vadnere GP, Pathan AR, Kulkarni BU, Abhay KS. Diplocyclopus palmatus: A phytopharmacological review. Int J Res Chem. 2013;3(1):157- 9.

4. Kamble SY, Patil SR, Sawant PS, Sawant S, Pawar SG, Singh EA. Studies on plants used in traditional medicine by Bhilla tribe of Maharashtra. Ind J Trad Knowl. 2010;9(3):591-98

5. Wabale AS. Vital ethnomedicinal plant species exploited in treating bronchitis. Bot. 2014:4(6):30-2.

6. Abhraham Z. 1981. Glimses of Indian Ethnobotany. Oxford publishing company. New Delhi. 308-20.

7. Shukla R, Chakravarty M, Gautam MP. Indigenous medicine used for treatment of gynecological disorders by tribal of Chhattisgarh, India, J Med Plants Res. 2008;2(12):356-60.

8. Kumar AP, Rao NB. Folk lore uses and preliminary phytochemical investigation on leaves, seeds extract of Diplocyclos palmatus (L.) C. Jeffrey Int J Adv Res. 2015;3(9):501-05.

9. Kavitha R, Chitti Babu CV, Subha TS. In vitro studies on antimicrobial and antioxidant properties of indigenous medicinal plants - Diplocyclos palmatus, Ctenolopis garcinii, and Kedrostis rostrata. Am J Bio pharm Biochem Life Sci. 2012;1:A58.

10. Bhavani MB, Ismail SM, Sampath KKK, Nethra NS. Leelavathi S. Evaluation of in vitro antioxidant activity of a few wild Cucurbitaceae plants against cancer. Int $J$ Pharm Res Bio Sci. 2013;2(6):529-36.

11. Kadam P. Bodhankar SL. Analgesic and anti-inflammatory activity of seed extracts of Diplocyclos palmatus (L.) C. Jeffrey. Int J Pharm Bio Sci. 2013;4(3): 970-8.

12. Mahanthesh MC, Jalalpure SS. Pharmacognostical evaluation and anticonvulsant activity of leaves of Diplocyclos palmatus Linn. Int J Pharm Bio Sci. 2015;6(4):734-51.

13. Tripathi J. Kumari R, Ashwlaya VD, Bansal P, Singh R. Anti diabetic Activity of Diplocyclos palmatus Linn. in Streptozotocin-Induced Diabetic Mice. Ind J
Pharm Edu Res. 2012;46(4):352-9.

14. Venkateshwarlu G, Shantha TR, Shiddamallayya N, Ramarao V Kishore KR Giri SK, et al. Physicochemical and preliminary phytochemical studies on the fruits of "Shivalingi" [Diplocyclos palmatus (Linn.) Jeffrey]. Int J Ayur Med. 2001;2(1):20-6.

15. Ordonez AA, Gomez JD, Vattuone MA, Isla MI. Antioxidant activities of Sechium edule (Jacq.) swart extracts. Food Chem. 2006;97(3):452-8. https://doi. org/10.1016/j.foodchem.2005.05.024.

16. Srivastava S, Ankita M, Kumar D, Srivastava A, Sood A, Rawat AKS. Reversedphase high-performance liquid chromatography-ultraviolet photodiode array detector validated simultaneous quantification of six bioactive phenolic acids in Roscoea purpurea tubers and their In vitro cytotoxic potential against various cell lines. Phcog Mag. 2015;11:488-95. https://doi.org/10.4103/09731296.168944; PMid:26929586 PMCid:PMC4745222

17. Kumaran A, Karunakaran RJ. In vitro antioxidant activities of methanol extract of Phyllanthus species from India. Lebens Wiss Technol. 2007;40(2):344-52. https://doi.org/10.1016/j.Iwt.2005.09.011.

18. Prieto P, Pineda M, Aguilar M. Spectrophotometric quantitation of antioxidant capacity through the formation of a phosphomolybdenum complex: Specific application to the determination of Vitamin E. Anal Biochem. 1999;269(2):337-41. https://doi.org/10.1006/abio.1999.4019. PMid:10222007

19. Halliwell B, Gutteridge JM, Aruoma O. The deoxiribose method: a simple test to be assay for determination of rate constants for reaction of hydroxyl radicals. Ana. Biochem. 1987;165(1):215-9. https://doi.org/10.1016/0003-2697(87)90222-3.

20. Liyana-Pathirana CM, Shahidi F. Antioxidant activity of commercial soft and hard wheat (Triticum aestivum L.) as affected by gastric $\mathrm{pH}$ conditions. J Agric Food Chem. 2005;53(7):2433-40.https://doi.org/10.1021/jf049320i; PMid:15796575.

21. Misra A, Srivastava S, Verma S, Rawat AKS. Nutritional evaluation, antioxidant studies and quantification of poly phenolics, Roscoea purpurea tubers, BMC Res Notes. 2015;8(1):324. https://doi.org/10.1186/s13104-015-1290-x PMid:26223698 PMCid:PMC4518606.

22. Niranjan A, Barthwal J, Lehri A, Singh, DP, Govindrajan R, Rawat AKS, et.al Development and validation of an HPLC-UV-MS-MS method for identification and quantification of polyphenols in Artemisia pallen, Acta Chromatog. 2009:2(1):105-16.

23. Shukla PK, Misra A, Srivastava S, Rawat AKS. Reversed phase high-performance liquid chromatographic ultra-violet (photo diode array) quantification of oleanolic acid and its isomer ursolic acid for phytochemical comparison and pharmacological evaluation of three Leucas species used in ayurveda. Phcog Mag 2016;12:S159-64.https://doi.org/10.4103/0973-1296.182173; $\quad$ PMid:27279701 PMCid:PMC4883073.

\section{GRAPHICAL ABSTRACT}

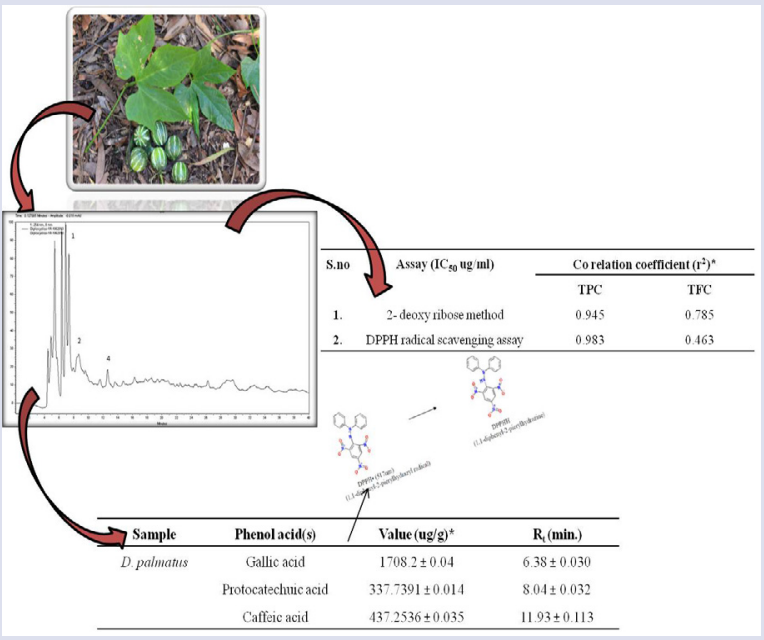

\section{SUMMARY}

- The investigation on aerial part of $D$. palmatus, reveals the presence of three phenolic markers.

- Gallic acid was found in highest concentration followed by caffeic acid and proto catechuic acid.

- $\quad \mathrm{IC}_{50}$ of test extract was obtained at concentration of 125.61 and 353.71 $\mathrm{ug} / \mathrm{ml}$ for hydroxyl radical scavenging activity by 2-deoxy ribose and DPPH stable radical respectively. 


\section{ABOUT AUTHORS}

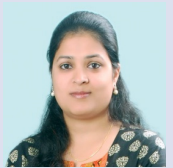

Ms. Ankita Misra: Is working as a Research Associate in Pharmacognosy Division at CSIR-National Botanical Research Institute; Lucknow, INDIA. She is working in the area of analytical chemistry on medicinal plants, chemotaxonomy, bio-prospection and natural product development, handling major analytical instruments including HPLC, HPTLC, OPLC and column chromatography for quality control of herbal drugs. She has 23 publications in peer reviewed journals and 1 patent is also to her credit.

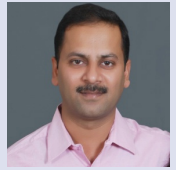

Dr. Sharad Srivastava: Is Principal Scientist in Pharmacognosy Division at CSIR-National Botanical Research Institute; Lucknow, INDIA. He has made significant contributions to quality control of crude drugs/products, chemotaxonomy, bio-prospection and natural product development and have developed quality parameters of single crude drugs (more than 70 medicinal plants) and also identified biomarkers for their quality control. He has contributed 30 monographs of single herbal drugs in Ayurvedic Pharmacopoeia of India. He has 125 publications in peer reviewed journals, 17 patents and developed some technologies/formulations, few has already been transferred to industry.

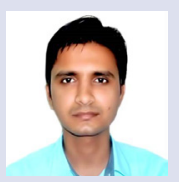

Pushpendra Kumar Shukla: Is working as Senior Research Fellow in Pharmacognosy and Ethnopharmacology division, CSIR- National Botanical Research Institute, Lucknow, India. He is working in the area of analytical chemistry on medicinal plant, chemotaxonomy and handling of sophisticated instrument like AAS, HPLC, HPTLC, OPLC and UV spectrophotometer for identification, quantification of bioactive metabolites and standardization and quality control of herbal drugs.

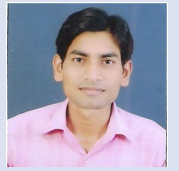

Bhanu kumar: Is post graduated in Botany, working as SRF at Pharmacognosy and Ethnopharmacology Division, CSIR-NBRI, Lucknow. Research interest involves chemo profiling of medicinal plants with emphasis on enumerating chemotypic variations arising in industrially important medicinal plants growing in different phytogeographical zones. Actively involved in field survey for collection of medicinal plants from the wild and establishing herbal drug standardization parameters. Published original research papers in national and internationally referred journals with a cumulative impact factor of 9.79 .

Cite this article: Misra A, Shukla PK, Kumar B, Niranjan A, Rawat AKS, Srivastava S. Simultaneous-HPLC Quantification of Phenolic Acids in Traditionally used Ayurvedic Herb Diplocyclos palmatus (L.) Jeffry. Pharmacogn J. 2017; 9(4): 483-7. 